\title{
Mental illnesses and their impact on the Brazilian workforce: an analysis of the cost of sick leave and pensions
}

\author{
Antônio G. da Silva, ${ }^{1,2}$ iD Alexandre L. Serpa, ${ }^{3}$ iD Antonio E. Nardi, ${ }^{4}$ iD Felix H.P. Kessler, ${ }^{5}$ (iD \\ Mayra I. Pinheiro, ${ }^{6}$ (iD Josierton C. Bezerra, ${ }^{7}$ iD Leandro F. Malloy-Diniz ${ }^{8,9}$ iD \\ ${ }^{1}$ Universidade do Porto, Porto, Portugal. ${ }^{2}$ Associação Brasileira de Psiquiatria (ABP), Rio de Janeiro, RJ, Brazil. ${ }^{3}$ Universidade Presbiteriana \\ Mackenzie, São Paulo, SP, Brazil. ${ }^{4}$ Instituto de Psiquiatria, Universidade Federal do Rio de Janeiro (UFRJ), Rio de Janeiro, RJ, Brazil. \\ ${ }^{5}$ Universidade Federal do Rio Grande do Sul (UFRGS), Porto Alegre, RS, Brazil. ${ }^{6}$ Ministério da Saúde, Brasília, DF, Brazil. ${ }^{7}$ Universidade \\ Potiguar (UnP), Natal, RN, Brazil. ${ }^{8}$ Universidade Federal de Minas Gerais (UFMG), Belo Horizonte, MG, Brazil. ${ }^{9}$ Universidade FUMEC, \\ Belo Horizonte, MG, Brazil.
}

The burden of mental illnesses worldwide transcends their evident impact on individuals and their families, and has become an urgent issue in public policy. Previous studies have suggested a $44.8 \%$ lifetime prevalence of mental disorders in Brazil. ${ }^{1}$ Doran \& Kinchin ${ }^{2}$ report that the annual cost of mental illness to developed countries is about $4 \%$ of gross domestic product. According to the World Health Organization, ${ }^{3}$ mental disorders accounted for $25.3 \%$ of all years lived with a disability in low-income countries, and an estimated $33.5 \%$ in middle-income countries.

Between 2007 and 2017, mental and behavior problems were the third leading cause of sick leave in Brazil. For the same period, sick leave represented $52 \%$ of all social benefits disbursed, and around $50 \%$ of claims were associated with mood disorders. ${ }^{4}$

We report an analysis of official data obtained from the Citizen Information Service of the National Social Security Institute (SIC INSS) regarding sick leave and ill-health pensions in Brazil from January to November 2020. Considering all information where an ICD code was provided, mental illness was the fourth leading cause of ill health retirement ( $7.2 \%$ of reported ICD codes) and the third leading cause of temporary sick leave $(13.7 \%$ of reported ICD codes).

We also report an analysis of official data provided by the Unified Benefits Information System (Sistema Único de Informações de Benefícios, SUIBE) regarding all active benefits paid to people with mental disorders. As of October 2020, there were 65,453 employed individuals temporarily off work due to mental illness, representing around $8 \%$ of all sick-leave benefits paid. Furthermore, 284,292 citizens are currently retired due to mental health disorders (around 9\% of all current permanent benefits paid by the social security system). Considering the total

Correspondence: Antonio Egidio Nardi, Laboratório de Pânico e Respiração, Instituto de Psiquiatria, Universidade Federal do Rio de Janeiro, Rua Visconde de Pirajá, 407/702, CEP 22410-003, Rio de Janeiro, RJ, Brazil.

E-mail: antonioenardi@gmail.com

Submitted Nov 23 2020, accepted Nov 30 2020, Epub Mar 222021. costs of social security for the year 2019 (BRL 50.5 billion), we consider that the annual cost to taxpayers of care for mental illness by the public social security system in Brazil could be estimated at BRL 7.4 billion (USD 1.37 billion). ${ }^{5}$

The leading psychiatric diagnostics related to sick leave and retirement due to illness is presented in Table 1. Mood, anxiety, and psychotic disorders seem to be more associated with both sick leave and retirement due to disability. Since the diseases or disorders related to temporary and permanent absence from work are the same (or, at least, remarkably similar), questions are arising about the relevance of increasing the availability of efficacious medical and psychological therapies before disorders worsen to the point of excluding these individuals from the workforce.

It is also important to consider other forms of impairment, such as absenteeism, presenteeism, reduced work quality and efficiency, and staff overload. Therefore, to address the growing challenge posed by the increasing incidence of mental disorders, mental health professionals must be aware of working conditions, promote early diagnosis, and develop evidence-based treatments.

One particular, urgent concern is the added burden of mental health disorders during the COVID-19 pandemic as an issue for public policy. ${ }^{6}$ In particular, the impact of workplace stress on mental health during pandemics is worrisome $^{7}$ and may have further impact on the workforce, prompting even further increases in sick leave and permanent disability.

Although this is not yet reflected by the data, we do expect a possible rise in requests for sick leave in the upcoming months, related both to the advancing "fourth wave" 6 of the COVID-19 epidemic and to the current 
Table 1 Most prevalent ICD codes associated with absence from work for mental health reasons in the Brazilian public social security system, October 2020

\begin{tabular}{|c|c|c|c|c|c|c|c|}
\hline \multirow{3}{*}{$\begin{array}{l}\text { ICD-10 } \\
\text { F32 Major depressive } \\
\text { disorder, single episode }\end{array}$} & \multicolumn{3}{|c|}{ Temporary absence } & \multirow{3}{*}{$\begin{array}{l}\text { ICD-10 } \\
\text { F20 Schizophrenia }\end{array}$} & \multicolumn{3}{|c|}{ Permanent absence/retirement } \\
\hline & \multirow{2}{*}{$\frac{n}{6,063}$} & \multicolumn{2}{|c|}{ Monthly cost* } & & \multirow{2}{*}{$\frac{n}{37,471}$} & \multicolumn{2}{|c|}{ Monthly cost* } \\
\hline & & $\begin{array}{c}\text { BRL } \\
10,240,203.05\end{array}$ & $\begin{array}{c}\text { USD } \\
1,896,333.90\end{array}$ & & & $\begin{array}{c}\text { BRL } \\
59,384,285,64\end{array}$ & $\begin{array}{c}\text { USD } \\
10,997,089,93\end{array}$ \\
\hline $\begin{array}{l}\text { F32.2 Major depressive } \\
\text { disorder, single } \\
\text { episode, severe without } \\
\text { psychotic features }\end{array}$ & 4,473 & $\begin{array}{c}\text { BRL } \\
7,728,474.49\end{array}$ & $\begin{array}{c}\text { USD } \\
1,431,198.98\end{array}$ & $\begin{array}{l}\text { F20.0 Paranoid } \\
\text { schizophrenia }\end{array}$ & 26,081 & $\begin{array}{c}\text { BRL } \\
40,274,920,36\end{array}$ & $\begin{array}{c}\text { USD } \\
7,458,318,59\end{array}$ \\
\hline $\begin{array}{l}\text { F33 Major depressive } \\
\text { disorder, recurrent }\end{array}$ & 3,744 & $\begin{array}{c}\text { BRL } \\
6,035,068.86\end{array}$ & $\begin{array}{c}\text { USD } \\
1,117,605.34\end{array}$ & $\begin{array}{l}\text { F32 Major depressive } \\
\text { disorder, single episode }\end{array}$ & 15,493 & $\begin{array}{c}\text { BRL } \\
31,422,114,03\end{array}$ & $\begin{array}{c}\text { USD } \\
5,818,910,01\end{array}$ \\
\hline $\begin{array}{l}\text { F33.2 Major depressive } \\
\text { disorder, recurrent } \\
\text { severe without } \\
\text { psychotic features }\end{array}$ & 3,172 & $\begin{array}{c}\text { BRL } \\
5,211,706.73\end{array}$ & $\begin{array}{l}\text { USD } \\
965,130.88\end{array}$ & $\begin{array}{l}\text { F29 Unspecified } \\
\text { psychosis not due to a } \\
\text { substance or known } \\
\text { physiological condition }\end{array}$ & 14,724 & $\begin{array}{c}\text { BRL } \\
25,186,149,80\end{array}$ & $\begin{array}{c}\text { USD } \\
4,664,101,81\end{array}$ \\
\hline F31 Bipolar disorder & 3,065 & $\begin{array}{c}\text { BRL } \\
4,866,832.51\end{array}$ & $\begin{array}{c}\text { USD } \\
901,265.28\end{array}$ & $\begin{array}{l}\text { F33 Major depressive } \\
\text { disorder, recurrent }\end{array}$ & 11,529 & $\begin{array}{c}\text { BRL } \\
22,040,327,96\end{array}$ & $\begin{array}{c}\text { USD } \\
4,081,542,21\end{array}$ \\
\hline F20 Schizophrenia & 2,782 & $\begin{array}{c}\text { BRL } \\
3,905,623.17\end{array}$ & $\begin{array}{c}\text { USD } \\
723,263.55\end{array}$ & F31 Bipolar disorder & 10,644 & $\begin{array}{c}\text { BRL } \\
20,061,330,40\end{array}$ & $\begin{array}{c}\text { USD } \\
3,715,061,19\end{array}$ \\
\hline $\begin{array}{l}\text { F41.2 Mixed anxiety } \\
\text { and depressive } \\
\text { disorder }\end{array}$ & 2,694 & $\begin{array}{c}\text { BRL } \\
4,753,812.89\end{array}$ & $\begin{array}{c}\text { USD } \\
880,335.72\end{array}$ & $\begin{array}{l}\text { F32.2 Major depressive } \\
\text { disorder, single episode, } \\
\text { severe without psychotic } \\
\text { features }\end{array}$ & 10,451 & $\begin{array}{c}\text { BRL } \\
22,470,816,50\end{array}$ & $\begin{array}{c}\text { USD } \\
4,161,262,31\end{array}$ \\
\hline $\begin{array}{l}\text { F20.0 Paranoid } \\
\text { schizophrenia }\end{array}$ & 2,533 & $\begin{array}{c}\text { BRL } \\
3,573,492.81\end{array}$ & $\begin{array}{l}\text { USD } \\
661,757.93\end{array}$ & $\begin{array}{l}\text { F33.3 Major depressive } \\
\text { disorder, recurrent, } \\
\text { severe with psychotic } \\
\text { symptoms }\end{array}$ & 9,544 & $\begin{array}{c}\text { BRL } \\
18,241,257,26\end{array}$ & $\begin{array}{c}\text { USD } \\
3,378,010,60\end{array}$ \\
\hline $\begin{array}{l}\text { F32.3 Major depressive } \\
\text { disorder, single } \\
\text { episode, severe with } \\
\text { psychotic features }\end{array}$ & 2,516 & $\begin{array}{c}\text { BRL } \\
3,818,689.78\end{array}$ & $\begin{array}{c}\text { USD } \\
707,164.77\end{array}$ & $\begin{array}{l}\text { F33.2 Major depressive } \\
\text { disorder, recurrent } \\
\text { severe without psychotic } \\
\text { features }\end{array}$ & 9,255 & $\begin{array}{c}\text { BRL } \\
19,125,799,46\end{array}$ & $\begin{array}{c}\text { USD } \\
3,541,814,71\end{array}$ \\
\hline $\begin{array}{l}\text { F41 Other anxiety } \\
\text { disorders }\end{array}$ & 2,449 & $\begin{array}{c}\text { BRL } \\
4,326,960.67\end{array}$ & $\begin{array}{c}\text { USD } \\
801,289.01\end{array}$ & $\begin{array}{l}\text { F32.3 Major depressive } \\
\text { disorder, single episode, } \\
\text { severe with psychotic } \\
\text { features }\end{array}$ & 8,878 & $\begin{array}{c}\text { BRL } \\
17,857,124,23\end{array}$ & $\begin{array}{c}\text { USD } \\
3,306,874,86\end{array}$ \\
\hline
\end{tabular}

Source: Sistema Único de Informações de Benefícios (SUIBE).

$*$ USD exchange rate $=5.40 \mathrm{BRL}$ (November 10th, 2020).

prediction of a prolonged pandemic state. These worrisome scenarios will cause public expenditure on social security to rise in a background of population-wide mental health issues. Also, our country may face yetunknown short- and long-term impacts on the economy due to the ensuing reduction of the economically active population.

Finally, evidence-based practices suggest that, besides early diagnosis and treatment, prevention and mental health promotion strategies are cost-beneficial, desirable resources to be adopted and encouraged by clinicians and policymakers. In particular, "lifestyle factors" such as physical activity, diet quality, less smoking, and sleep quality are strongly related to mental health. These factors can be considered targets for interventions to improve quality of life in patients with prevalent mental disorders such as major depression, ADHD, schizophrenia, and drug addiction, ${ }^{8}$ especially

during this difficult, stressful period of the COVID-19 pandemic.

\section{Disclosure}

The authors report no conflicts of interest.

\section{References}

1 Viana MC, Andrade LH. Lifetime prevalence, age and gender distribution and age-of-onset of psychiatric disorders in the São Paulo Metropolitan Area, Brazil: results from the São Paulo Megacity Mental Health Survey. Braz J Psychiatry. 2012;34:249-60.

2 Doran CM, Kinchin I. Economics of mental health: providing a platform for efficient mental health policy. Appl Health Econ Health Policy. 2020;18:143-5.

3 World Health Organization (WHO). Mental Health Action Plan 20132020. Geneva: WHO; 2013.

4 Macedo JW, da Silva AB. Afastamentos do trabalho no Brasil por transtornos mentais e comportamentais (TMC): o que revelam 
os números da previdência social? Metod Pesq Admin. 2018;3: 39-49.

5 Brasil, Secretaria da Previdência. Anuário estatístico da previdência social - AEPS. 2019 [Internet]. [cited 2020 Nov 25] https://www.gov.br/ previdencia/pt-br/acesso-a-informacao/dados-abertos/previdenciasocial-regime-geral-inss/dados-abertos-previdencia-social

6 da Silva AG, Miranda DM, Diaz AP, Teles AL, Malloy-Diniz LF, Palha AP. Mental health: why it still matters in the midst of a pandemic. Braz J Psychiatry. 2020;42:229-31.
7 da Silva AG, Pinheiro M, Trés LM, Malloy-Diniz LF. Working during pandemics: the need for mental health efforts to prevent the outbreak of mental disorders at the workplace. Braz J Psychiatry. 2021;43: 116-7.

8 Firth J, Solmi M, Wootton RE, Vancampfort D, Schuch FB, Hoare E, et al. A meta-review of "lifestyle psychiatry": the role of exercise, smoking, diet and sleep in the prevention and treatment of mental disorders. World Psychiatry. 2020;19:360-80. 